\title{
ИСТОРИЧЕСКАЯ АНТРОПОЛОГИЯ
}

Caк K.B.

DOI: $10.7256 / 2222-1972.2014 .4 .14037$

При иитировании этой статьи сноска на дог обязательна

\section{Вехи профессиональной биографии великого князя Константина Константиновича}

\begin{abstract}
Аннотация. В статъе показаны основные вехи профессиональной биографии великого князя Константина Константиновича (1856-1915), представленные в контексте социально-политических событий иарствований трех последних императоров. Цель работь - на примере биографии К. Р. рассмотреть особенности развития каръеры иленов династии Романовых, выявить объективные и субвективные факторы, влиявшие на их общественно-политическую активность, и показать, как изменялось значение членов династии в государственной жизни Российской империи в позднеимперский период. Автор приходит к выводу, что карьернъй рост великого князя Константина Константиновича зависел от представлений монархов о роли членов династии в общественно-политической жизни. В то же время назначения могли быть следствием иниииативы влиятельных сановников, желавших таким образом реализовать свои амбичии. Решающее влияние на каръеру великих князей оказала позичия Александра III, который не считал нужным привлекать родственников к государственным делам. В то же время назначения могли быть следствием инициативы влиятельных сановников, желавших таким образом реализовать свои амбичии. Решающее влияние на карьеру великих князей оказала позичия Александра III, который не считал нужным привлекать родственников к государственным делам. Это привело к тому, ито впоследствии, при Николае II, Константин Константинович обладал возможностью повлиять на государственную жизнь, но не смог реализовать свои иниииативъ. Отсутствие опьта создавало у великого князя неуверенность в свочх способностях государственного деятеля и делало частную жизнъ привлекательнее жизни публичного лича. Таким образом, на примере профессиональной биографии великого князя Константина Константиновича можно видеть, как илены династии утрачивали свои основополагающие роли в жизни государства, что привело в конечном итоге к кризису династии как политического института власти.
\end{abstract}

Ключевые слова: в.к. Константин Константинович, в.к. Константин Николаевич, династия Романовых, Александр II, Александр III, Николай II, комитеты грамотности, Императорская академия наук, военно-учебнъе заведения, первал русскал революиия.

Annotation. The article illustrates the key milestones in the professional biography of the Grand duke Konstantin Konstantinovich (1856-1915), presented in the context of the socio-political events during the reigns of the last three emperors. The aim of the study is to analyse, on the example of Konstantin Romanov's biography, the career development particularities of the Romanov dynasty members, to reveal the objective and subjective factors that influenced their sociopolitical activity, and to show how the significance of the dynasty's members in the state life of the Russian empire changed in the course of the late-imperial period. The author comes to the conclusion that the career advancement of the Grand duke Konstantin Konstantinovich depended on the monarchs' individual perceptions of the role of dynasty members in the socio-political life of the state. At the same time, professional appointments could be made on high officials' initiatives, which were eager to reach their ambitions through this. The opposition against Alexander III had a decisive influence on the careers of the Grand dukes of his time, as the emperor did not deem necessary to engage his relatives in state affairs. This, in consequence, under Nicholas II led to Konstantin Konstantinovich having the possibility to influence state life, but not to fulfil his initiatives. The absence of experience gave the Grand duke a sense of incertitude in his abilities as a statesman and made his private life more appealing than the life of a public figure. Thus, on the example of the professional biography of the Grand duke Konstantin Konstantinovich, one can see how the dynasty's members lost their fundamental roles in the life of the state, which ultimately led to the crisis of the dynasty as a political institute of authority.

Key words: Grand duke Konstantin Konstantinovich, Grand duke Konstantin Nikolaevich, Romanov dynasty, Alexander I, Alexander II, Alexander III, Nicholas II, literacy committees, Imperial academy of sciences, military schools, first Russian revolution. 
प лены Императорской фамилии имели особый социальный и политический статус. От благополучия династии зависело благополучие самой империи. Ключевая роль великих князей как августейших особ состояла в несении службы престолу и Отечеству, которая подавала пример остальным подданным монарха. Так говорилось в «Учреждении об Императорской фамилии», своде прав и обязанностей, по воле Николая I вошедшем в основные государственные законы. Но уже в царствование его сына Александра II ситуация меняется, и для молодого поколения великих князей необходимость жертвовать своими интересами в выборе профессионального пути становится не столь очевидной. Не стал исключением и великий князь Константин Константинович, более известный как августейший поэт К. Р. Анализ основных вех карьеры великого князя даст возможность рассмотреть на его примере, от чего зависели исполнение основополагающей обязанности членов династии, их продвижение по службе, как в конечном итоге әто повлияло на состояние династии как политического института власти.

Биография великого князя Константина Константиновича не раз попадала в поле зрения исследователей. Наиболее подробно изучена его творческая деятельность, интерес к которой возник еще при его жизни и не прекращается до сих пор [6, 8, 9, 30, 31, 34, 36, 37, 42, 43, 46]. Роль великого князя в общественно-политических процессах изучена эпизодически. Советские исследователи обращались к ней для иллюстрации политического и социального кризиса самодержавия и династии Романовых [24, 25, 26, $29,41]$. Так, П. А. Зайончковский характеризует Константина Константиновича как человека, выделяющегося «наличием интеллекта» из среды других великих князей, но утверждает, что его политические взгляды были «примитивны и реакционны» и никакого участия в государственной жизни он не принимал. Иная позиция представлена в статьях современного исследователя Д. А. Андреева. Государственная деятельность великого князя показана с точки зрения его вовлеченности в неформальный политический процесс в царствование Николая II [1, 2, 3]. В связи с участием великого князя в общественной жизни интерес представляют исследования, посвященные его деятельности на посту президента Санкт-Петербургской академии наук, в которых отражена его роль в развитии научного потенциала этого учреждения $[4,40]$. Таким образом, в историографии представлены основные направления профессиональной деятельности Константина Константиновича. Однако профессиональный путь великого князя в целом и влияние объективных и субъективных факторов на его карьеру не были предметом отдельного исследования.

Великий князь Константин Константинович родился 12 августа 1858 г. Августейшего младенца по традиции и установленному в доме Романовых порядку назначили шефом Тифлисского гренадерского полка, определили в лейбгвардии Конный и Измайловский полки и в Гвардейский экипаж [28, л. 1об.]. Это были одни из самых престижных полков империи. Константин Николаевич, генерал-адмирал и глава Морского министерства, прочил своему второму сыну будущее на морской службе. Основные отцовские амбиции были направлены на старшего сына Николая, поэтому младший имел больше внутренней свободы отдаваться своим увлечениям. Однако все изменилось в 1874 г., когда наследника генерал-адмирала, виновного в краже драгоценностей в родительском доме и императорском дворце, объявили душевнобольным и навсегда выслали из столицы. В результате этой трагической истории пятнадцатилетний Константин получал права первородства. В разгар самого скандала он хорошо понимал, что теперь на него ляжет дополнительная ответственность: «Немного испугался, не слишком ли худо Николе, и не останусь ли я старшим сыном; меня это очень испугало, потому что я вовсе не хочу быть старшим сыном» [10, л. 18об.]. С этого момента великий князь начинает обостренно чувствовать, что он должен доказать своей службой, что достоин нового статуса в императорском семействе. В 1876 г. во время производства в мичманы Александр II вручил моряку эполеты и несколько раз повторил, что он «должен быть вдвойне достоин звания офицера (здесь и далее подчеркивание великого князя. - K. С.)». Вечером новоиспеченный мичман размышлял в дневнике: «Я понял, это вдвойне относилось к тому, что я должен восстановить честь моих родителей, пострадавшую от поведения Николы» [11, л. 74об.-75].

Вскоре Константину Константиновичу представилась такая возможность. В 1877 г. разгорелась Русско-турецкая война. Великий князь, как и многие другие его августейшие родственники, принял в ней участие. Годом ра- 


\section{Исторический журнал: научные исследования № 4 (22) • 2014}

DOI: $10.7256 / 2222-1972.2014 .4 .14037$

нее Константин Николаевич, не исключая уже тогда возможности начала военных действий с участием России, учил своего наследника: «Не забывай тогда, кто ты и что ты. Помни, что ты русский, что ты Романов, что ты племянник русского царя, помни, что ты моряк и служишь под нашим русским флагом и Андреевским крестом, честь которого должно отстаивать до последней капли крови» $[38$, л. Зоб.]. Константин Константинович буквально воспринял наставления отца. За поджог турецких судов он получил высшую воинскую награду - Георгиевский крест.

Вернувшись в Петербург, августейший моряк продолжал служить в Гвардейском экипаже, пока во время очередного учебного плавания в 1880-1881 гг. не принял окончательного для себя решения оставить флот и посвятить себя исключительно гражданской службе. Для Романовых это было совершенно нетипичным решением. Осенью 1881 г. Константин Константинович так оправдывал свою волю в письме к отцу: «Я мечтаю всеми силами души и тела служить на пользу Родины, продолжать начатое тобою дело освобождения и просвещения и посвятить всю жизнь на труд по улучшению быта нашего православного народа и духовенства» [39, л. 41об.]. В ответ же на обвинения отца в лицемерии и лжи он писал: «Меня влекло и к гражданской службе - это началось уже в 78 году, когда я начал заниматься правом и политической экономией. Я очень хорошо знал, что мне невозможно было в мои юные годы занимать какой-нибудь важный пост; мне было необходимо послужить. Тут я ухватился за плавание, которое притом давало мне возможность выбраться из ненавистной петербургской обстановки. Я знал, что дальнее плавание для меня единственный выход, единственное средство к достижению моей заветной мечты. По возвращении из плавания на меня смотрели бы уже как на более или менее созревшего человека, способного занять какое-нибудь гражданское место» [39, л. 44]. Именно в это время он всерьез увлекся поэзией и вскоре заявил о себе как о поэте К. Р.

Константину Константиновичу удалось настоять на своем, несмотря на нелицеприятные упреки и уговоры отца. Не встретил он противодействия и состороны императораАлександра II. Однако, находясь вдали от Родины и в отрыве от политической ситуации, он не учел одного крайне важного обстоятельства. 1 марта 1881 г. кровавое покушение унесло жизнь царя-освободителя. На престол взошел Александр III, который по-своему видел обязанности членов династии на службе государству. Эпоха Великих реформ и «раскрепощения личности» - когда великий князь мог всерьез надеяться вопреки традиции оставить военную службу и занять гражданский пост - уходила в прошлое. И первым из членов династии перемены почувствовал на себе великий князь Константин Николаевич, которого венценосный племянник уволил со всех занимаемых должностей. Молодой поэт не понял этого сигнала, хотя искренне сопереживал отцу и осуждал действия монарха. 7 июля 1881 г. он писал: «Как русский до мозга костей, я не могу не оплакивать такого поступка возлюбленного государя относительно верного слуги своего отечества, оказавшего ему неизгладимые заслуги. Я предвижу, что этот поступок ничем не оправдается в будущем, и жалею государя более, быть может, чем тебя. Ты выходишь чистый, ничем не запятнанный из водоворота государственной деятельности $<\ldots>$ тебе сопутствуют сожаления твоих сподвижников. Но чем объяснят свой поступок твои гонители?» [39, л. 33об.-34].

Время правления Александра III не было удачным для великих князей с точки зрения продвижения по карьерной лестнице. Император не желал видеть родственников на политической сцене и не допускал их вмешательства в свои дела. Это отразилось даже в законодательном поле - в 1886 г. он внес изменение в «Учреждение об Императорской фамилии». Теперь не праправнуки императоров записывались в родословную книгу в качестве князей императорской крови, как это было ранее, а правнуки. Тем самым они лишались значительной части содержания и привилегий при поступлении на военную службу. Нежелание императора допускать кого-либо до самодержавной власти почувствовал на себе даже наследник Николай Александрович, который в 1895 г. в одном разговоре с Константином Константиновичем признался, что Александр III долго не вводил его в курс политических дел: «Ники сказал мне с лукавой улыбкой: "Папа меня тоже назначил неожиданно и не предупредив"» [16, л. 36]. Константин Константинович же, которого всегда ассоциировали с его выдающимся отцом, казалось, имел еще меньше шансов участвовать в государственной жизни.

Хотя К. Р. оставил службу во флоте, никакого «гражданского» поста он не получил. В феврале 1884 г. великий князь принял командование ротой Измайловского полка. На тот момент ему 
Историческая антропология

DOI: $10.7256 / 2222-1972.2014 .4 .14037$

исполнилось 26 лет. Для сравнения: в том же возрасте его отец возглавил Морское министерство. К. Р. быстро освоился на новой должности и уже на следующий день отметил, что чувствует себя «власть имущим». Служебные обязанности не были для него обременительными, и он с неменьшим энтузиазмом занимался поэзией. В это время Константин Константинович активно пишет и издает стихи, заводит близкие знакомства с писателями, музыкантами, художниками. В полку великий князь устраивал «Измайловские досуги», на которых офицеры читали стихи, участвовали в театральных постановках, приглашали выступать с лекциями поэтов и писателей. В итоге в день своего тридцатилетия Константин Константинович записал в дневнике: «Жизнь моя и деятельность вполне определились. Для других я военный, ротный командир, в близком будущем полковник, а там, лет через 5-6, - командир полка и, как мне хотелось бы, Тифлисского, моего, на Кавказе. Для себя же - я поэт. Вот мое истинное призвание» [13, л. 6об.-7]. В это время государственные дела его интересовали не более чем остальных столичных обывателей, а императрице Марии Федоровне он даже признался, что в политике смыслит мало и не считает себя вправе в ней участвовать [12, л. 42].

Однако спустя три года, в 1889 г., великого князя Константина Константиновича ждало новое назначение. Александр III через министра народного просвещения графа И. Д. Делянова предложит ему занять пост президента Санкт-Петербургской академии наук. Чем руководствовался при этом Александр III, остается неизвестным. Исследователь Р. Уортман объяснял это так: К. Р. был одним из тех членов династии, которые пользовались «уважением императора», благодаря чему «получали высокие должности» $[44,379]$. Другим мотивом могло послужить то, что Александру III было хорошо известно о творческой деятельности великого князя и его широких связях в кругах представителей культуры. Пост этот был хоть и престижным, но обремененным многочисленными проблемами, связанными с необходимостью переработки устаревшего устава. Туманны были его позиции с точки зрения возможности участвовать в государственной жизни и политике. Тем не менее тот факт, что предшественником Константина Константиновича был граф Д. А. Толстой, до 1880 г. занимавший пост министра народного просвещения, а с 1882 г. - министра внутренних дел, свидетельствовал о возмож- ных перспективах в будущем. Тем более что граф И. Д. Делянов, в подчинении которого оказывался великий князь, непрозрачно намекал ему на свой преклонный возраст и на то, что присматривает себе преемника. Константин Константинович отнесся к новому назначению серьезно и ответственно, но, как он позднее написал в своем дневнике, от возможности занять пост министра народного просвещения отказался [18, л. 150об.] (к сожалению, подробности этого разговора К. Р. с графом Деляновым неизвестны).

Неожиданным для К. Р. оказалось и еще одно новое продвижение по службе в 1891 г. По указу Александра III Константин Константинович принял от своего кузена великого князя Сергея Александровича командование Преображенским полком - первым гвардейским полком империи, который располагался на Миллионной улице, т. е. в непосредственной близости к Зимнему дворцу. Его командир имел право личного доклада императору. Однако Константин Константинович, не имевший больших амбиций, не отнесся к повороту судьбы как к дополнительной возможности выстроить более тесные деловые отношения с императором. Более того, он сожалел, что ему приходится оставлять столь полюбившийся Измайловский полк [15, л. 69].

Тем не менее Преображенский полк сблизил Константина Константиновича с цесаревичем Николаем Александровичем, который до своего воцарения был командующим одним из преображенских батальонов. Специфика службы в одном полку, когда однополчане воспринимались как члены одной большой семьи, сблизила дядю с двоюродным племянником. Этот контакт не был создан Константином Константиновичем намеренно, в надежде на будущий карьерный рост, но именно он открыл перед великим князем новые перспективы. Николай II, взойдя на престол после смерти отца 20 октября 1894 г., нуждался в помощниках. В это время определенное влияние на него оказывали родные дяди - Сергей, Павел, Владимир и Алексей Александровичи. Государственные деятели, выдвинувшиеся во время правления Александра III (Н. Х. Бунге, К. П. Победоносцев, С. Ю. Витте), также искали расположения нового монарха, чтобы укрепить свое на него влияние. Неслучайно Константин Константинович, подводя итог первого года царствования Николая II, писал о преемственности его курса: «Мы вступили во 2-й год царствования нынешнего государя. Он до сих пор не начинал менять ничего в государ- 


\section{Исторический журнал: научные исследования № 4 (22) • 2014}

DOI: $10.7256 / 2222-1972.2014 .4 .14037$

ственном управлении; все, что за истекший год было сделано, есть исполнение предначертаний покойного царя. Никаких перемен не состоялось из уважения к памяти почившего; даже не было приступлено к перемене в обмундировании войска, чем обыкновенно ознаменовывалось у нас начало каждого нового царствования. В этом строгом соблюдении всего прежнего Николай II представляет единственный пример. Говорят, что теперь, по истечении года, начнутся различные преобразования. Посмотрим» [16, л. 140-140об.].

Однако для Константина Константиновича перемены начались раныше. 4 марта 1895 г. он получил назначение в Комитет финансов. Инициатором этого шага выступил министр финансов С. Ю. Витте, который на тот момент готовил проведение денежной реформы и искал союзников среди членов династии. Двоюродный дядя императора, находившийся с ним в доверительных отношениях и известный довольно либеральными взглядами, идеально подходил для роли «проводника» идей министра. В то же время великий князь, по его личному признанию, ничего не смыслящий в делах финансов, мог легко попасть под влияние своего патрона. Действительно, несмотря на то что во время заседаний К. Р. старался вникать в тонкости законопроектов и придерживаться собственного мнения, оно почти всегда совпадало с позицией Витте.

Назначение в Комитет финансов сблизило Константина Константиновича с Н. Х. Бунге. На одном из заседаний он предложил К. Р. принять участие в учреждении особого комитета грамотности и распространения полезных знаний, который заменил бы собой Московский комитет при Императорском московском обществе сельского хозяйства и Санкт-Петербургский при Вольном экономическом обществе. Великий князь «с восторгом согласился», и Бунге пообещал доложить об этом Николаю II. Ответ императора не заставил себя ждать: «На всеподданнейшем моем докладе о том, что было бы крайне важно поставить преобразовываемый ныне С[анкт-]Петербургский комитет грамотности под высокое покровительство особы Императорской фамилии, посвятившей с комитетом себя делу народного просвещения, государю императору, в 20 день сего марта, благоугодно было собственноручно начертать: “Думаю поручить руководство вел[икому] князю Константину Константиновичу” [ 16, л. 42].
Это было назначение, о котором Константин Константинович мечтал с детства. Он тут же принялся за переработку устава. По замыслу великого князя, следовало учредить общество, занимавшееся просвещением народа, с множеством филиалов на местах, члены которых и назначались, и избирались. Техническую сторону вопроса по проведению законопроекта взял на себя управляющий делами Комитета министров А. Н. Куломзин. Уже 27 апреля устав «Общества ревнителей просвещения народа» был практически доработан и представлен членам специальной комиссии. В ближайшее время планировалось рассмотреть его в Комитете министров. Однако 1 мая Константин Константинович узнал, что Николай II отложил обсуждение проекта на осень [16, л. 63]. Причина была в противодействии со стороны К. П. Победоносцева, сторонника церковно-приходских школ. Его усилия дали свои плоды: хотя работа по уставу осенью возобновилась, но возникали все новые сложности, исходившие на этот раз от других министров. В конце концов великий князь сам признал, что его деятельность не имеет перспектив: «Чтобы угодить министрам, надо по возможности ограничить состав Общества, а для надлежащего развития его деятельности следовало бы этот состав расширить. И я думаю, что мой проект будет бессмыслен» [16, л. 143]. Опасения Константина Константиновича подтвердились, и его деятельность по преобразованию комитетов так ничем и не закончилась.

Итак, Константин Константинович в начале царствования Николая II продвинулся по карьерной лестнице, приобрел опыт участия в государственных преобразованиях и получил возможность влиять на государственные дела. Неслучайно, что именно в это время появилось множество слухов о его возможном назначении на министерские посты, и прежде всего на пост министра народного просвещения. Однако это было результатом не его личной инициативы, а стечением обстоятельств. Он, не имея надлежащего политического опыта и твердости характера, не смог реализовать свои преобразовательные проекты. Как лицу новому, К. Р. было крайне сложно разобраться в жившей по своим законам политической кухне. Тем более что он к этому и не стремился. «"Comment avec votre intelligence ne vous occupper que du front?” (“Как с Вашими способностями Вы занимаетесь только военной

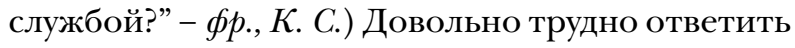
на такие речи» [17, л. 145 об.], - записал он в 
дневнике диалог с графиней Е. А. ВоронцовойДашковой, супругой министра двора. Для себя же он мечтал исключительно о том, чтобы стать членом Государственного совета [18, л. 47об.].

В 1900 г. Константина Константиновича ждал новый поворот карьеры. Он получил назначение на должность главного начальника военно-учебных заведений (правда, ему пришлось пережить болезненное расставание с Преображенским полком). На этот раз инициатором был его дядя, великий князь Михаил Николаевич, председатель Государственного совета. Повидимому, он не имел корыстных целей и, делая это предложение Николаю II, исходил из личных симпатий. Пост этот был несамостоятельный, т. к. великий князь попадал в подчинение военному министру. Реакция А. Н. Куропаткина на появление августейшего подчиненного была неоднозначной. Практически сразу же между ними разгорелся конфликт. По предположению управляющего двором Константина Константиновича, его друга и советника П. Е. Кеппена, министр хотел «поставить в зависимость от себя великого князя, пользующегося расположением общества», приставил к нему своих помощников, через которых можно было бы на него влиять, и был уверен, что К. Р. станет «только по наружности» управлять вверенным ему ведомством [19, л. 11]. Великий князь, напротив, сразу назначил себе в помощники единомышленников и, встретив сопротивление со стороны Куропаткина, стал добиваться независимости Главного управления военно-учебных заведений от военного министерства. Это вылилось в столь острое противостояние, что разрешать его пришлось на самом высоком уровне - на докладе императору. Вопреки надеждам К. Р. Николай II не захотел ничего менять. Это больно ударило по амбициям великого князя, и он решил рано или поздно добиться своего. Формальную самостоятельность Константин Константинович получил только в 1910 г., став генералом-инспектором.

Определяющую роль в карьере К. Р. сыграли революционные события 1905-1907 гг., после которых он утратил желание активно участвовать в общественно-политической жизни. После издания манифеста 12 декабря 1904 г. Николай II через Витте передал великому князю бумагу, в которой велел «пригласить» его в работу Комитета министров на правах его члена для обсуждения вопроса об изменении временных правил о печати и «облегчении» ее «от излишних стеснений» [21, л. 162-162об.]. На первом же заседании было решено создать вневедомственную комиссию с привлечением в ее состав сенаторов и членов Академии наук. Это позволяло Константину Константиновичу надеяться, что именно он возглавит преобразование цензурных правил. Однако по не зависящим от него обстоятельствам и здесь он не смог реализовать себя - активное антиправительственное участие некоторых академиков в революционных событиях и их желание создать независимый «Союз учащих» показали политическую ненадежность академии. Уговоры президента, призывавшего своих подопечных встать на сторону правительства, которое само к ним обратилось за помощью в деле печати, успеха не имели. В результате 23 января 1905 г. Николай II назначил председателем Особого совещания для пересмотра действующих о цензуре и печати постановлений не великого князя, а члена Государственного совета и директора Публичной библиотеки Д. Ф. Кобенко [22, л. 36об.]. С тех пор монарх ни разу не обратился к двоюродному дяде за советом, и Константин Константинович никогда не принимал участия в многочисленных совещаниях, в т. ч. с участием других великих князей, по преобразованию политической системы.

Константин Константинович во время первой русской революции имел возможность повлиять на политический процесс неформальными методами. Дважды он получал предложение от придворных лиц (первое - еще до революционных событий, в июне 1904 г., второе - в июле 1906 г.) возглавить группу великих князей, чтобы оградить императора от вредного влияния министров и помочь ему справиться с возникшим политическим кризисом. Однако от предложений әтих К. Р. отказался. Первый отказ он объяснил тем, что не доверяет великому князю Александру Михайловичу, с которым ему предстояло вступить в союз. Кроме того, К. Р. руководствовался и этическими соображениями: «Втираться в доверие государя, насильственно добиваться влияния над ним, хотя бы во имя высших целей, - благородно, достойно ли? Цель оправдывает ли средство?» [20, л. 99об.-100]. Второй отказ - бессилием перед революцией и невозможностью повлиять на ситуацию [23, л. 44об.]. Профессиональные неудачи Константина Константиновича, невозможность реализовать на практике преобразовательные замыслы привели к тому, что великий князь стал довольствоваться тем, что имел. Как и прежде, он преданно служил престолу, но это походило, ско- 


\section{Исторический журнал: научные исследования № 4 (22) • 2014}

DOI: $10.7256 / 2222-1972.2014 .4 .14037$

рее, на рутинное исполнение привычных обязанностей, нежели на созидание чего-то нового в общественно-политической жизни империи.

Таким образом, назначения на новые должности были лишь отчасти результатом усилий и достижений К. Р. В большей степени они зависели либо от личных планов глав императорского дома, мотивы которых остаются до конца неясными, либо от просьб виднейших сановников, намеревавшихся с помощью великого князя и его близкого положения к правящему монарху реализовать свои политические амбиции. Это приводило к отсутствию у великих князей необходимого опыта для принятия в дальнейшем самостоятельных решений в общественно-политической жизни. Константин Константинович, получивший возможность в начале царствования Николая II сделать карьеру государственного деятеля, не смог реализовать ее на деле. Представления великого князя о политической жизни и инструментах принятия решений отставали от конкретных практик его времени. Пример профессиональной биографии великого князя Константина Константиновича свидетельствует о том, что в конце XIX - начале XX в. члены правящего дома утрачивали свои основополагающие роли в жизни государства, заложенные традицией и закрепленные законом.

\section{Библиография:}

1. Андреев Д. А. Император Николай II в первые месяцы царствования: внешние влияния и самостоятельные решения // Российская история. 2011. № 4. С. 114-125.

2. Андреев Д. А. Борьба ревнителей: просветительские альтернативы в начале царствования Николая II // Вестник Свято-Тихоновского православного университета. Серия: История. История Русской Православной Церкви. 2012. № 1 (44). С. 58-74.

3. Андреев Д. А. Студенческие беспорядки и борьба в правительственных верхах зимой-весной 1899 г. // Российская история. 2012. № 1. С. 59-68.

4. Басаргина Е. Ю. Императорская академия наук на рубеже XIX-XX веков (Очерки истории). М.: Индрик, 2008. 656 c.

5. Власть и реформы. От самодержавной к советской России. СПб.: Издательство СПбГУ, 1997. 356 с.

6. Волгин И. Л. Колеблясь над бездной. Достоевский и русский императорский дом. М.: Центр гуманитарного образования, 1998. $656 \mathrm{c.}$

7. Воронин В. Е. Русская самодержавная власть и либеральная правительственная группировка в условиях политического кризиса (конец 70-х - середина 80-х гг. XIX в.). М.: Спутник+, 2010. 220 с.

8. Гаршин Е. М. Три поэмы (А. Н. Майкова, графа А. А. Голенищева-Кутузова и К. Р.). Критический этюд. СПб.: Типография В. В. Комарова, 1889.26 с.

9. Гурлянд И. Я. Характерные черты поэзии «К. Р.». Ярославль: Типография губернского правления, 1900.11 с.

10. Дневник вел. кн. Константина Константиновича // Государственный архив Российской Федерации. Ф. 660. Оп. 1. Д. 4.

11. Дневник вел. кн. Константина Константиновича // Государственный архив Российской Федерации. Ф. 660. Оп. 1. Д. 6.

12. Дневник вел. кн. Константина Константиновича // Государственный архив Российской Федерации. Ф. 660. Оп. 1.Д. 31.

13. Дневник вел. кн. Константина Константиновича // Государственный архив Российской Федерации. Ф. 660. Оп. 1. Д. 35.

14. Дневник вел. кн. Константина Константиновича // Государственный архив Российской Федерации. Ф. 660. Оп. 1. Д. 36.

15. Дневник вел. кн. Константина Константиновича // Государственный архив Российской Федерации. Ф. 660. Оп. 1. Д. 38.

16. Дневник вел. кн. Константина Константиновича // Государственный архив Российской Федерации. Ф. 660. Оп. 1. Д. 42.

17. Дневник вел. кн. Константина Константиновича // Государственный архив Российской Федерации. Ф. 660. Оп. 1. Д. 43.

18. Дневник вел. кн. Константина Константиновича // Государственный архив Российской Федерации. Ф. 660. Оп. 1. Д. 44.

19. Дневник вел. кн. Константина Константиновича // Государственный архив Российской Федерации. Ф. 660. Оп. 1. Д. 48.

20. Дневник вел. кн. Константина Константиновича // Государственный архив Российской Федерации. Ф. 660. Оп. 1. Д. 53.

21. Дневник вел. кн. Константина Константиновича // Государственный архив Российской Федерации. Ф. 660. Оп. 1. Д. 55.

22. Дневник вел. кн. Константина Константиновича // Государственный архив Российской Федерации. Ф. 660. Оп. 1. Д. 56.

23. Дневник вел. кн. Константина Константиновича // Государственный архив Российской Федерации. Ф. 660. Оп. 1. Д. 57.

24. Зайончковский П. А. Российское самодержавие в конце XIX столетия. М.: Мысль, 1970. 444 с.

25. Зайончковский П. А. Кризис самодержавия на рубеже 1870-1880-х гг. М.: Издательство Московского университета, 1964. $511 \mathrm{c}$.

26. Захарова Л. Г. Кризис самодержавия накануне революции 1905 года // Вопросы истории. 1978. № 8. С. 119-140.

27. Иванова Н. А., Желтова В. П. Сословное общество Российской империи (XVIII - начало XX века). М.: Новый хронограф, 2009. $752 \mathrm{c}$.

28. Копия послужного списка // Государственный архив Российской Федерации. Ф. 660. Оп. 2. Д. 7.

29. Кризис самодержавия в России. 1895-1917. Л.: Наука, 1984. 664 с.

30. Кузьмина Л. И. Августейший поэт К. Р.: Стихи разных лет. Личность. Творчество. СПб.: Лики России, 1995. 256 с.

31. Кузьминский К. С. К. Р. Поэт любви и красоты (1882-1907 гг.). М.: Товарищество типография А. И. Мамонтова, 1907. 16 с.

32. Ливен Д. Аристократия в Европе. 1815-1914. СПб.: Академический проект, 2000. 364 с.

33. Лобашкова Т. А. Из истории формирования личного фонда великого князя Константина Константиновича // Отечественные архивы. 2000. № 3. С. 18-26. 


\section{Историческая антропология}

DOI: $10.7256 / 2222-1972.2014 .4 .14037$

34. Лобашкова Т. А. «Я не великий поэт...» Великий князь Константин Константинович Романов в истории русской культуры // Московский журнал. 1996. № 10. С. 16-24.

35. Матонина Э. Е. «К. Р.». М.: Молодая гвардия, 2008. 671 с.

36. Михайлов Д. Лирика К. Р. в связи с историей русской поэзии во вторую половину ХІХ в. СПб.: П. П. Сойкин, 1901. 167 с.

37. Нелюбин Г. Великий князь Константин Константинович. Жизнь и творчество. 1858-1915. Прага, 1916. 34 с.

38. Письма и телеграммы в. кн. Константина Николаевича (отца) в. кн. Константину Константиновичу // Государственный архив Российской Федерации. Ф. 660. Оп. 2. Д. 114.

39. Письма в. к. Константина Константиновича отцу в. к. Константину Николаевичу // Государственный архив Российской Федерации. Ф. 772. Оп. 1. Д. 780.

40. Соболев В. С. Августейший президент. СПб.: Искусство-СПб., 1996. 183 с.

41. Соловьев Ю. Б. Самодержавие и дворянство в конце XIX века. Л.: Наука, Ленинградское отделение, 1973. 383 с.

42. Соколов Л. А. Религиозно-нравственные мотивы в мире царственного певца. Киев: Типография акционерного общества «Петр Барский в Киеве», 1915. 64 с.

43. Стечкин Н. Я. Константин Романов (25 лет поэтической деятельности). СПб.: Типолитография В. В. Комарова, 1904. $31 \mathrm{c}$.

44. Уортман Р. Сценарии власти. Мифы и церемонии русской монархии. Т. 2. М.: ОГИ, 2004. 608 с.

45. Шевырев А. П. Русский флот после Крымской войны: Либеральная бюрократия и морские реформы. М.: Издательство МГУ, 1990. 184 с.

46. Языков Д. Д. Августейший поэт (К. Р.). Критико-биографический очерк. М.: Университетская типография, 1903. 40 с.

\section{References (transliterated):}

1. Andreev D. A. Imperator Nikolai II v pervye mesyatsy tsarstvovaniya: vneshnie vliyaniya i samostoyatel'nye resheniya // Rossiiskaya istoriya. 2011. № 4. S. 114-125.

2. Andreev D. A. Bor'ba revnitelei: prosvetitel'skie al'ternativy v nachale tsarstvovaniya Nikolaya II // Vestnik Svyato-Tikhonovskogo pravoslavnogo universiteta. Seriya: Istoriya. Istoriya Russkoi Pravoslavnoi Tserkvi. 2012. № 1 (44). S. 58-74.

3. Andreev D. A. Studencheskie besporyadki i bor'ba v pravitel'stvennykh verkhakh zimoi-vesnoi $1899 \mathrm{~g}$. // Rossiiskaya istoriya. 2012. № 1. S. 59-68.

4. Basargina E. Yu. Imperatorskaya akademiya nauk na rubezhe XIX-XX vekov (Ocherki istorii). M.: Indrik, 2008. $656 \mathrm{~s}$.

5. Vlast' i reformy. Ot samoderzhavnoi k sovetskoi Rossii. SPb.: Izdatel'stvo SPbGU, 1997. 356 s.

6. Volgin I. L. Koleblyas' nad bezdnoi. Dostoevskii i russkii imperatorskii dom. M.: Tsentr gumanitarnogo obrazovaniya, 1998. $656 \mathrm{~s}$.

7. Voronin V. E. Russkaya samoderzhavnaya vlast' i liberal'naya pravitel'stvennaya gruppirovka v usloviyakh politicheskogo krizisa (konets 70-kh - seredina 80-kh gg. XIX v.). M.: Sputnik+, 2010. $220 \mathrm{~s}$.

8. Garshin E. M. Tri poemy (A. N. Maikova, grafa A. A. Golenishcheva-Kutuzova i K. R.). Kriticheskii etyud. SPb.: Tipografiya V. V. Komarova, $1889.26 \mathrm{~s}$.

9. Gurlyand I. Ya. Kharakternye cherty poezii «K. R.». Yaroslavl': Tipografiya gubernskogo pravleniya, 1900. $11 \mathrm{~s}$.

10. Dnevnik vel. kn. Konstantina Konstantinovicha // Gosudarstvennyi arkhiv Rossiiskoi Federatsii. F. 660. Op. 1. D. 4.

11. Dnevnik vel. kn. Konstantina Konstantinovicha // Gosudarstvennyi arkhiv Rossiiskoi Federatsii. F. 660. Op. 1. D. 6.

12. Dnevnik vel. kn. Konstantina Konstantinovicha // Gosudarstvennyi arkhiv Rossiiskoi Federatsii. F. 660. Op. 1.D. 31.

13. Dnevnik vel. kn. Konstantina Konstantinovicha // Gosudarstvennyi arkhiv Rossiiskoi Federatsii. F. 660. Op. 1. D. 35.

14. Dnevnik vel. kn. Konstantina Konstantinovicha // Gosudarstvennyi arkhiv Rossiiskoi Federatsii. F. 660. Op. 1. D. 36.

15. Dnevnik vel. kn. Konstantina Konstantinovicha // Gosudarstvennyi arkhiv Rossiiskoi Federatsii. F. 660. Op. 1. D. 38.

16. Dnevnik vel. kn. Konstantina Konstantinovicha // Gosudarstvennyi arkhiv Rossiiskoi Federatsii. F. 660. Op. 1. D. 42.

17. Dnevnik vel. kn. Konstantina Konstantinovicha // Gosudarstvennyi arkhiv Rossiiskoi Federatsii. F. 660. Op. 1. D. 43.

18. Dnevnik vel. kn. Konstantina Konstantinovicha // Gosudarstvennyi arkhiv Rossiiskoi Federatsii. F. 660. Op. 1. D. 44.

19. Dnevnik vel. kn. Konstantina Konstantinovicha // Gosudarstvennyi arkhiv Rossiiskoi Federatsii. F. 660. Op. 1. D. 48.

20. Dnevnik vel. kn. Konstantina Konstantinovicha // Gosudarstvennyi arkhiv Rossiiskoi Federatsii. F. 660. Op. 1. D. 53.

21. Dnevnik vel. kn. Konstantina Konstantinovicha // Gosudarstvennyi arkhiv Rossiiskoi Federatsii. F. 660. Op. 1. D. 55.

22. Dnevnik vel. kn. Konstantina Konstantinovicha // Gosudarstvennyi arkhiv Rossiiskoi Federatsii. F. 660. Op. 1. D. 56.

23. Dnevnik vel. kn. Konstantina Konstantinovicha // Gosudarstvennyi arkhiv Rossiiskoi Federatsii. F. 660. Op. 1. D. 57.

24. Zaionchkovskii P. A. Rossiiskoe samoderzhavie v kontse XIX stoletiya. M.: Mysl', 1970. 444 s.

25. Zaionchkovskii P. A. Krizis samoderzhaviya na rubezhe 1870-1880-kh gg. M.: Izdatel'stvo Moskovskogo universiteta, 1964. $511 \mathrm{~s}$.

26. Zakharova L. G. Krizis samoderzhaviya nakanune revolyutsii 1905 goda // Voprosy istorii. 1978. № 8. S. 119-140.

27. Ivanova N. A., Zheltova V. P. Soslovnoe obshchestvo Rossiiskoi imperii (XVIII - nachalo XX veka). M.: Novyi khronograf, 2009. $752 \mathrm{~s}$.

28. Kopiya posluzhnogo spiska // Gosudarstvennyi arkhiv Rossiiskoi Federatsii. F. 660. Op. 2. D. 7.

29. Krizis samoderzhaviya v Rossii. 1895-1917. L.: Nauka, 1984. $664 \mathrm{~s}$.

30. Kuz'mina L. I. Avgusteishii poet K. R.: Stikhi raznykh let. Lichnost'. Tvorchestvo. SPb.: Liki Rossii, 1995. $256 \mathrm{s.}$

31. Kuz'minskii K. S. K. R. Poet lyubvi i krasoty (1882-1907 gg.). M.: Tovarishchestvo tipografiya A. I. Mamontova, 1907. $16 \mathrm{~s}$.

32. Liven D. Aristokratiya v Evrope. 1815-1914. SPb.: Akademicheskii proekt, 2000. $364 \mathrm{~s}$. 


\section{Исторический журнал: научные исследования № 4 (22) 2014}

DOI: $10.7256 / 2222-1972.2014 .4 .14037$

33. Lobashkova T. A. Iz istorii formirovaniya lichnogo fonda velikogo knyazya Konstantina Konstantinovicha // Otechestvennye arkhivy. 2000. № 3. S. 18-26.

34. Lobashkova T. A. «Ya ne velikii poet...» Velikii knyaz' Konstantin Konstantinovich Romanov v istorii russkoi kul'tury // Moskovskii zhurnal. 1996. № 10. S. 16-24.

35. Matonina E. E. «K. R.». M.: Molodaya gvardiya, 2008.671 s.

36. Mikhailov D. Lirika K. R. v svyazi s istoriei russkoi poezii vo vtoruyu polovinu XIX v. SPb.: P. P. Soikin, 1901. 167 s.

37. Nelyubin G. Velikii knyaz' Konstantin Konstantinovich. Zhizn' i tvorchestvo. 1858-1915. Praga, 1916. 34 s.

38. Pis'ma i telegrammy v. kn. Konstantina Nikolaevicha (ottsa) v. kn. Konstantinu Konstantinovichu // Gosudarstvennyi arkhiv Rossiiskoi Federatsii. F. 660. Op. 2. D. 114.

39. Pis'ma v. k. Konstantina Konstantinovicha ottsu v. k. Konstantinu Nikolaevichu // Gosudarstvennyi arkhiv Rossiiskoi Federatsii. F. 772. Op. 1. D. 780.

40. Sobolev V. S. Avgusteishii prezident. SPb.: Iskusstvo-SPb., 1996.183 s.

41. Solov'ev Yu. B. Samoderzhavie i dvoryanstvo v kontse XIX veka. L.: Nauka, Leningradskoe otdelenie, 1973. $383 \mathrm{s.}$

42. Sokolov L. A. Religiozno-nravstvennye motivy v mire tsarstvennogo pevtsa. Kiev: Tipografiya aktsionernogo obshchestva «Petr Barskii v Kieve», 1915. 64 s.

43. Stechkin N. Ya. Konstantin Romanov (25 let poeticheskoi deyatel'nosti). SPb.: Tipolitografiya V. V. Komarova, 1904. $31 \mathrm{s.}$

44. Uortman R. Stsenarii vlasti. Mify i tseremonii russkoi monarkhii. T. 2. M.: OGI, 2004. $608 \mathrm{~s}$.

45. Shevyrev A. P. Russkii flot posle Krymskoi voiny: Liberal'naya byurokratiya i morskie reformy. M.: Izdatel'stvo MGU, 1990. $184 \mathrm{~s}$.

46. Yazykov D. D. Avgusteishii poet (K. R.). Kritiko-biograficheskii ocherk. M.: Universitetskaya tipografiya, 1903. 40 s. 